\title{
ВПЛИВ СВРОІНТЕГРАЦІЙНИХ ПРОЦЕСІВ НА РОЗВИТОК ВИЩОЇ МЕДИЧНОЇ ОСВІТИ
}

М. С. Осійчук

\author{
Міністерство охорони здоров'я України
}

\section{INFLUENCE OF EUROINTEGRATION PROCESSES ON THE HIGHER MEDICAL EDUCATION DEVELOPMENT}

\author{
Ministry of Public Health of Ukraine
}

\author{
M.S. Osiychuk
}

У статті аналізується взаємозв'язок якості підготовки медичного персоналу та досягнення високих стандартів життя у суспільстві, обговорюються питання впливу євроінтеграційних процесів на проблеми освітньої конкурентоспроможності держави.

The interconnection of the quality of the healthcare personnel preparation with high standards of living is analyzed in the article; problems of educational competitionship of the state are discussed.

Вступ. Конституція України (ст. 3 та 49) визначає життя і здоров'я людини найвищими соціальними цінностями держави. Для сфери державного управління важливими питаннями $є$ вплив вищої освіти на формування фахового рівня медичного персоналу, роль у цьому євроінтеграційних процесів і Болонського освітнього формату. Завданням дослідження $\epsilon$ аналіз взаємозв'язку процесів, що відбуваються у вищій школі, із основною метою державної кадрової політики у медичній сфері - забезпечити державу високопрофесійним, ініціативним, патріотично налаштованим персоналом і управлінськими кадрами нового типу, здатними взяти на себе відповідальність і успішно вирішувати назрілі загальнодержавні й регіональні проблеми.

Існує широкий спектр думок щодо взаємозв'язків професійного рівня медичного персоналу, стану його освіченості, виявлення мотиваційної ролі освітніх процесів як регулятора підвищення якості медичної допомоги. Ці питання не знайшли достатнього висвітлення у вітчизняних наукових та практичних дослідженнях. За даними Світового банку, підвищення рівня загальної освіченості економічно активного населення на один рік сприяє збільшенню ВВП на 9 \% [7]. Подібна динаміка притаманна усій сфері охороні здоров’я, враховуючи наміри України щодо інтеграції до європейського та світового товариства.

Українськими вченими, що проводять дослідження у сфері освіти, все частіше звертається увага на інтеграційні процеси в освітньому просторі, зокрема на приєднання України до Болонського процесу, який розглядається не лише як один з інструментів нашої інтеграції в Свропу, а й інструмент реалізації загальної світової тенденції сьогодення - глобалізаційні процеси [3].

Загальноукраїнські аспекти взаємозв' язку та інтеграції української освіти до Європейського освітнього простору досліджувалися та досліджуються такими українськими вченими, організаторами системи освіти, у тому числі медичної, як В. Байденко, М. Степко, Я. Болюбаш, В. Журавський, М. Згуровський, В. Луговий, В. Янковий, В. Пєрєдєрій, В. Москаленко, Ю. Вороненко $[2,4,7,8]$ тощо.

Метою статті $€$ аналіз впливу на формування фахового рівня медичного персоналу інтеграції української освіти до Європейського освітнього простору та впровадження новітніх освітніх процесів, зокрема:

- визначення впливу інтеграційних освітніх процесів на процес навчання у вищих медичних навчальних закладах (далі - ВНЗ) України, зокрема ВНЗ Міністерства охорони здоров'я України;

- доцільність впровадження та застосування європейських підходів у навчальному процесі ВНЗ;

- вплив запровадження Болонських підходів у вищій медичній школі на підвищення фахового рівня медичного персоналу.

Основна частина. Кадрове забезпечення сфери охорони здоров'я $є$ однією 3 ключових проблем реформи медичного обслуговування. Існує безпосередня залежність результативності й ефективності будьякого управління від його кадрового потенціалу. Рівень медичного обслуговування суттєво впливає на жит-

(C) М. С. Осійчук 
тєдіяльність країни, здоров’я і добробут їі громадян, міжнародний авторитет держави. Проблема якості підготовки кадрів продукує проблему якості медичного обслуговування.

У процесі об'єднання Європи, який супроводжується формуванням спільного освітнього простору з єдиними вимогами, критеріями і стандартами, важливою метою є консолідація зусиль освітянської та наукової громадськості задля забезпечення належних умов підготовки професійних кадрів світового рівня. Цей інтеграційний процес, що сформувався під егідою Болонської декларації, спрямований на впровадження загальноєвропейських норм в освіті і науці та поширення національних культурних і науково-технічних надбань серед європейських країн [3].

Важливим позитивним аспектом Болонського процесу є освітнє зближення і згуртування європейських держав. Насамперед це створить принципово нову атмосферу відкритості і співпраці всіх європейських країн.

Для України, у культурно-цивілізаційному аспекті, європейська інтеграція - це входження до єдиної сім’ї європейських народів, повернення до європейських політичних і культурних традицій. Перспектива європейської інтеграції - це вагомий стимул для успіху, економічної і політичної трансформації, що може стати основою національної консолідації. Свропейська інтеграція, таким чином, стає ключовою ланкою відкриття України світові, переходу від закритого тоталітарного до відкритого демократичного суспільства [3].

Останнім часом зросла увага вищих навчальних закладів України, у тому числі й ВНЗ, підпорядкованих Міністерству охорони здоров’я України, до питань Болонського процесу. Перед нашою країною поставлено завдання привести систему вищої освіти у відповідність до вимог Болонської конвенції. Однак це не є самоціллю, а нагальна потреба поліпшити якість вітчизняної вищої освіти у плані ії змістовного наповнення.

Вища освіта сьогодні нагромадила багато проблем, які, на жаль, застарілими методами вирішити неможливо. До загальноукраїнських проблем належать:

-зростає загрозлива тенденція до погіршення якості вищої освіти. 3 введенням навчання за рахунок фізичних та юридичних осіб показник якості навчання постійно знижується. Українське суспільство ще не навчилось “купляти знання", часто це нормальне поняття замінюється поняттям “купляти диплом”;

- продовжується нехтування передовими науковими дослідженнями у закладах освіти, які є основою університетської підготовки. Вітчизняна система наукових ступенів складна порівняно з загальноєвропейською, і це ускладнює мобільність викладачів та науковців у Свропі;

- існує напруга у зв'язках між освітянами і працедавцями, між сферою освіти і ринком праці. Готувати фахівців за кошти державного бюджету без визначеного працевлаштування - це недопустима розкіш для держави. Недопустима розкіш для України також готувати таких фахівців, які ще протягом року адаптуються на робочому місці. За європейськими стандартами, дипломований фахівець 3 приходом на виробництво відразу займає робоче місце й професійно виконує свої посадові обов' язки. Гарантією цього має бути диплом і авторитет вищого навчального закладу, який він закінчив.

Також існує багато специфічних проблем української медичної вищої освіти, заради вирішення яких вища медична школа повинна здійснити кардинальні структурні перетворення.

Ці структурні перетворення можуть знайти себе, насамперед, у положеннях Болонського процесу, основними $з$ яких $\epsilon$ :

- побудова Свропейського простору вищої освіти як передумови розвитку мобільності громадян з можливістю їх працевлаштування;

- посилення міжнародної конкурентоспроможності систем вищої освіти;

- досягнення більшої сумісності та порівнянності систем вищої освіти;

- формування та зміцнення інтелектуального, культурного, соціального та науково-технічного потенціалу окремих країн та Свропи у цілому;

- підвищення визначальної ролі університетів у розвитку національних та європейських культурних цінностей;

- змагання 3 іншими системами вищої освіти за студентів, кошти та престиж.

Стояти осторонь від цього медична спільнота Україна не може. Освітянське медичне середовище зацікавлене діяти на всіх напрямках Болонського процесу [3].

Ми розуміємо, що вищим навчальним закладам Міністерства охорони здоров'я України необхідно активізувати проведення таких реформ. Оскільки реформа медичного обслуговування не можлива без реформування медичної освіти.

3 цією метою відповідно до наказу МОЗ України від 29.01.2013 р. № 62 “Про впровадження Протокольного рішення наради ректорів вищих медичних (фармацевтичного) навчальних закладів IV рівня 
акредитації та закладів післядипломної освіти МО3 України від 15 січня 2013 року та затвердження складу робочих груп щодо його виконання" здійснюється робота робочих груп, до яких залучені представники вищих навчальних закладів IV рівня акредитації та закладів післядипломної освіти, представники структурних підрозділів з питань охорони здоров'я обласних державних адміністрацій.

Робочими групами будуть розроблені проекти нормативно-правових актів МО3 України з питань реформування та підвищення ефективності післядипломної медичної та фармацевтичної освіти, розвитку системи безперервного розвитку лікарів та провізорів; удосконалення системи державної підсумкової атестації студентів вищих медичних (фармацевтичного) навчальних закладів IV рівня акредитації MO3 України, методології складання та оновлення бази запитань тестових ліцензійних іспитів “Крок”; удосконалення системи інформатизації та модернізації навчального процесу у вищих медичних (фармацевтичному) навчальних закладах IV рівня акредитації та закладах післядипломної освіти MO3 України; розроблення методичних рекомендацій щодо державного розподілу, порядку працевлаштування та зарахування в інтернатуру випускників вищих медичних (фармацевтичного) навчальних закладів IV рівня акредитації МОЗ України.

Окрім того, з метою поліпшення якості організації підготовки лікарів та провізорів Міністерством охорони здоров'я України буде:

- затверджено рейтингові показники оцінки результатів діяльності вищих навчальних закладів та їх керівників;

- забезпечено подальшу роботу Моніторингової групи з оцінки навчально-методичної діяльності вищих медичних (фармацевтичних) навчальних закладів I - IV рівнів акредитації MO3 України;

- збільшено у 2013 - 2014 навчальному році показник успішного складання ліцензійних інтегрованих іспитів “Крок 1", “Крок 2” та “Крок 3” з усіх напрямів та спеціальностей підготовки до 55-70 \% правильних відповідей;

- затверджено план заходів щодо посилення контролю за якістю підготовки фахівців з метою прийняття МОЗ України відповідних управлінських рішень;

- активізовано роботу опорних кафедр вищих навчальних закладів щодо оновлення типових навчальних планів та програм, створення національних підручників та навчальних посібників;

- забезпечено ретельну перевірку результатів діяльності опорних кафедр, проведення опорними кафедрами семінарів та нарад за участі представників профільних кафедр інших вищих навчальних закладів за підсумками роботи у 2011 - 2012 навчальному році;

- збільшено до 15 тисяч питань банк тестових завдань ліцензійних інтегрованих іспитів “Крок 1", "Крок 2" i “Крок 3" з усіх напрямів та спеціальностей підготовки і забезпечено відкритість та прозорість їх розробки, якісний відбір із залученням експертів представників вищих навчальних закладів;

- забезпечено координацію роботи вищих навчальних закладів із організаціями, підприємствами та установами щодо залучення іноземних громадян для навчання в Україні;

- здійснено моніторинг якості проведення виховної роботи з іноземними студентами.

Також MO3 України проводиться робота у напрямку поліпшення організації якості підготовки лікарів за кредитно-модульною системою організації навчального процесу. Забезпечення конкурентоспроможності вітчизняних студентів та науковців на ринку праці покладається на керівників вищих медичних навчальних закладів, для цього необхідно:

- оновити навчально-методичну базу та забезпечити належну підготовку науково-педагогічних кадрів для навчання студентів за новими напрямами і спеціальностями;

- оптимізувати підготовку науково-педагогічних кадрів вищої кваліфікації - докторів та кандидатів медичних наук і забезпечити резерв на кафедрах, які очолюють кандидати наук та особи пенсійного віку; - організувати належний контроль за своєчасним підвищенням кваліфікації науково-педагогічних кадрів, а також організацію систематичного підвищення кваліфікації викладачів, які працюють з іноземними студентами, зокрема 3 питань етнопедагогіки;

- зактивізувати роботу секторів (відділів) моніторингу якості освіти щодо розробки заходів, спрямованих на поліпшення якості підготовки студентів та удосконалення внутрішньої системи іï контролю;

- забезпечити студентів сучасними підручниками (посібниками) з грифами MO3 України та МОH України, виданими протягом останніх п'яти років. Першочергово здійснювати закупівлю (видання) національних підручників, розроблених на виконання наказу МОЗ України від 22 червня 2010 року № 502 "Про затвердження робочих груп з питань підготовки національних підручників для студентів вищих навчальних закладів IV рівня акредитації, підпорядкованих МОЗ України"; 
- створювати умови та забезпечувати ефективну роботу авторських колективів з числа викладачів вищих навчальних закладів щодо створення сучасних підручників і навчальних посібників, у тому числі на електронних носіях. Забезпечувати постійне оновлення електронних бібліотек;

- посилити контроль за реалізацією Наскрізної програми підготовки студентів медичних факультетів талікарів-інтернів вищих навчальних закладів для оволодіння практичними навичками та методиками, необхідними для роботи на посадах лікарів за спеціальністю “Загальна практика - сімейна медицина";

- завершити оснащення та уведення у дію навчальних міжкафедральних тренінгових центрів;

- затвердити та впровадити форми індивідуального обліку засвоєння студентами та лікарями-інтернами практичних навичок та методик, передбачених Наскрізною програмою підготовки студентів медичних факультетів та лікарів-інтернів вищих навчальних закладів для оволодіння практичними навичками та методиками, необхідними для роботи на посадах лікарів за спеціальністю “Загальна практика - сімейна медицина";

- забезпечити включення наукових видань університетів до Міжнародної наукометричної бази даних;

- удосконалити внутрішню систему забезпечення якості наукових досліджень та оприлюднення їх результатів у рейтингових міжнародних виданнях;

- модернізувати інтернет-ресурси вищих навчальних закладів щодо навчальних матеріалів із профільних дисциплін. Забезпечувати їх системне поповнення та оновлення, систематичне проведення навчальнонаукових тематичних відеоконференцій, подальшу розробку, впровадження та удосконалення сучасних інтерактивних навчальних систем із їхньою інтеграцією до професійних мереж;

- активізувати міжнародну співпрацю 3 метою взаємного обміну студентами, стажування викладачів у провідних зарубіжних наукових установах та вищих навчальних закладах, брати участь у міжнародних та вітчизняних академічних консорціумах, виставках, здійснювати пошук грантів для забезпечення професійної освітньої та наукової діяльності.

Реформування вищої школи має розпочинатися з головного - оптимізації навчального процесу та удосконалення системи впровадження кредитно-модульної системи. ВНЗ Міністерства охорони здоров' я не стоять осторонь тих перетворень, які зараз відбувають- ся у вищій освіті у цілому. Не знімаючи з порядку денного основного питання - забезпечення якісної підготовки лікарів та провізорів, нам необхідно спільно розпочати системну роботу щодо модернізації системи вищої медичної та фармацевтичної освіти, яка має відповідати міжнародним стандартам. Цей процес повинен відбуватися координовано - як на додипломному, так і післядипломному етапах підготовки спеціалістів.

Продовжуючи рух відповідно до Болонської декларації важливо уникнути зайвих ризиків, а також не звести перетворення до рівня поверхневих, косметичних, конференцій і розмов. Результати перетворень мають на меті надати молоді можливість, засвоюючи кращі традиції європейського освітянського простору, розбудувати наше суспільство до рівня передових і заможних країн.

Медичні університети як інноваційні осередки мають стати локомотивами реформування сфери охорони здоров’я. Україна сьогодні на переході від четвертого (постіндустріального) технологічного укладу до п'ятого (інформаційного) на основі економіки знань. Тоді як провідні країни світу уже готуються до шостого, в основі якого синтез біо- і нанотехнології, генна і медична інженерія, парапсихологія. Вже сьогодні потрібно думати про місце і роль вищих навчальних закладів у цих модернізаційних процесах, $\mathrm{i}$ рівень відповідальності їх керівників.

Стійке економічне зростання, розвинутий внутрішній ринок і стабільність можуть відбутися тільки у високоосвіченому суспільстві із високим рівнем надання медичної допомоги. Без нього не можна досягти високих стандартів життя. Як висновок, слід зазначити, що Болонський процес сприятиме формуванню цивілізованого ринку освітніх послуг, підвищенню інтелектуального потенціалу суспільства, зокрема його управлінського потенціалу, спричинить стійке економічне зростання держави і добробуту громадян.

Висновок. Перспективою подальших досліджень у цьому напрямку є наукове опрацювання і розробка стратегічного плану розвитку навчальних і наукових закладів системи охорони здоров' я України. За об'єднавчих процесів, які відбуваються в українському освітньому просторі, важливою метою є консолідація зусиль освітянської та наукової громадськості усіх вищих медичних навчальних закладів задля забезпечення належних умов підготовки професійних кадрів світового рівня. 


\section{Література}

1. Попченко Т. П. Реформування сфери охорони здоров’я в Україні: організаційне, нормативно-правове та фінансово-економічне забезпечення : аналіт. доп. / Т. П. Попченко. - К. : НІСД, 2012. - 96 с.

2. Байденко В. І. Болонський процес: структурна реформа вищої освіти Європи / В. І. Байденко. - М. : Дослід. центр проблем якості підготовки спеціалістів, Рос. новий ун-т, 2002. $-128 \mathrm{c}$.

3. Болонський процес як засіб інтеграції і демократизації європейської вищої школи : тематична збірка для професорсько-викладацького складу. -К. : КНЕУ, 2005.-234 с.

4. Журавський В. С. Болонський процес: головні принципи входження в європейський простір вищої освіти / В. С. Журавський, М. З. Згуровський. - Київ : Політехніка, 2003.
5. Ван дер Венде М. К. Болонская декларация: расширение доступности и повышение конкурентоспособности высшего образования в Европе / М. К. Ван дер Венде // Высшее образование в Европе. - 2000. - T. XXV, № 3.

6. Кладис Дионисис. Социальные аспекты Болонского процесса / Кладис Дионисис // Высшее образование в Европе. - 2003. - T. XXVIII, № 3 .

7. Луговий В. І. Управління освітою / В. І. Луговий. - К., 1997.-С. 71 .

8. Основні засади розвитку вищої освіти України в контексті Болонського процесу (документи і матеріали 2003 2004 рр.) / [авт. кол.: М. Ф. Степко, Я. Я. Болюбаш, В. Д. Шинкарук та ін.]; за ред. В. Г. Кременя. - Київ-Тернопіль : Вид-во ТДПУ, 2004. - 147 с. 